\title{
Afterword: Intersubjectivity and the Politics of Poststructuralism
}

The rhetoric of fallenness, as I have traced it in selected social and literary texts from the mid-Victorian period, expresses anxieties about what constitutes human agency and selfhood. As we have seen, there was a pervasive tendency to protect cherished conceptions of moral autonomy and stable identity by creating a category of feminine fallenness. Through depictions of fallenness, the many perceived threats to the self- to its coherence, freedom, and distinct recognizability - could be both exaggerated and displaced, and also eventually diminished and dismissed, ushered off the scene, as were so many fallen figures in Victorian literature. I have argued that encounters with the prostitute falter or miscarry because she is perceived, distortedly, as the mere effect of systemic forces environmental, economic, sexual, and aesthetic. As I demonstrate in Chapter 1, such distortions derive from the models of selfhood and agency that informed emergent scientific and sociological approaches to character. A powerful materialist approach to the self, deriving from associationism, utilitarianism, and reformist thought more generally, supported the elaboration of fallenness, which frequently took on the most extreme and threatening aspects of the new social understandings, particularly the tendencies toward atomism and mechanism. The figure of the fallen woman thus typically appeared as a profoundly isolated and determined subject, exiled from social relations and lacking the autonomy and coherence of the self-determining masculine self.

The Victorian depiction of fallenness also lights up a more general impasse in Victorian social thought, the tension between the sci- 
entific explanation of character and society, and the commitment to ethical and political transformation, both at the individual and social levels. This tension between fact and value takes on various guises in Victorian culture and is negotiated in different ways by those who broadly accept the doctrine of necessity, or the idea that human actions conform to uniform laws. In the Logic, John Stuart Mill insists that it is possible to reconcile a scientific explanation of character with a principle of moral freedom (which in turn allows an understanding of character as self-crafted). Likewise, Robert Owen subscribes to a principle of external character formation and, concurrently, to a principle of rational autonomy. In other instances, followers of the doctrine of necessity stress that sympathetic or disinterested feelings, which would form the basis for rejuvenated communities, are either as primary as hedonistic impulses, or will naturally evolve through the lessons of experience (which will teach us that what promotes happiness for others ultimately promotes happiness for us). ${ }^{1}$

Of course the literary writers I have examined did not forward explicitly philosophical positions on the disjunction between fact and value. Still, like the philosophers and cultural critics I examined in Chapter 1, these writers attempted to preserve notions of moral autonomy and redemptive sympathy even as they insisted on the pervasive power of larger social and aesthetic forces and structures. And sometimes these writers even challenged the dominant tendency to use figures of fallenness to draw off the more troubling aspects of Victorian conceptions of selfhood. Either by partly exposing dominant scapegoating mechanisms or by recasting the very notion of fallenness, writers were able to point toward the forms of social interaction that were being systematically foreclosed by the dominant discourse.

I have stressed such moments of critique and revision precisely because they either reveal or redress the deeper problems of atomism and mechanism in the rhetoric of fallenness and, by extension, in some influential Victorian approaches to individual and social identity. Dickens exhibits some self-consciousness about the scapegoating mechanisms directed toward the fallen, and he certainly uses their plight to focus social criticisms; but he does not significantly

1. As I discuss in Chapter 1, Mill also forwarded versions of these latter arguments. 
transform the dominant paradigms through which fallen subjectivity was conceived, and his moments of sympathy often remain sentimental, reinforcing a view of fallen women as fated to a perpetual, and profoundly isolating, self-condemnation. Gaskell suggests a deep complicity between instrumental reason and conventional views of fallenness, though her stress on the transformative powers of sympathetic communing, if greater than Dickens's, is still marred by asymmetries of power. Her elaboration of a more reciprocal and far-reaching model of class interaction at the end of North and South can be seen as exemplary of the kind of reconceptualization of social relations that this book aims to forward, as can Rossetti's gestures toward a positive conception of intersubjective indeterminacy and Barrett Browning's promotion of a dialectical interplay between aesthetic and intersubjective experience. In all of these instances, the model of selfhood counterposed to "fallenness" is one that is fundamentally relational, open-ended, and participatory; this conception of identity in turn lends tacit support to those instances where a writer aims to promote ethical norms of intersubjective mutuality or, in the case of Gaskell, more democratic processes of social transformation.

Here I want to extend the discussion of normativity, intersubjectivity, and agency to the poststructuralist terrain. Such an extension is profitable and instructive because of the deep parallels and continuities between the kinds of moral and social questions that exercised the Victorians and those that compel our attention today. Of course what I call "parallels" result in part from the inevitable ways in which contemporary concerns originally framed my readings of Victorian culture. Yet I believe there are historical continuities as well, insofar as the development of socially scientific approaches in the Victorian era eventually gave rise to dominant paradigms of thought in the twentieth century, predominantly those of sociology, linguistics, and structuralism, paradigms that continue to exert their force even on the "antisystematic" theories of poststructuralism. For despite the challenges that poststructuralism poses to the scientism of structuralism, it has nonetheless failed to redress adequately the fundamental problems of agency and normativity that plagued structuralism. Poststructuralism's primary emphases have been on indeterminacy and a radical alterity that functions at the symbolic or structural level. But this privileging of disruption at the systemic level derives from a residual objectivism within poststructuralism 
itself, one that profoundly disables the political and ethical projects of those cultural critics who employ poststructuralist paradigms in an untransformed way. It is this residual objectivism that allows us to discern similarities between contemporary and Victorian questions, despite manifold historical and cultural differences. For if a deep-seated objectivism characterizes the rhetoric of fallenness and inhibits the theorization of moral agency and intersubjectivity, the residual objectivism of poststructuralism has had similar effects on our own attempts at theoretical self-understanding.

We can take some measure of the continuities between Victorian and contemporary approaches to the question of agency by the interest that poststructuralist critics have brought precisely to protosociological or protomodernist aspects of Victorian discourse. Given Dickens's especially vivid sense of social determination, as well as his peculiarly modern conception of alienated self-reflexivity, it seems apt, for example, that D. A. Miller would privilege Dickens in his Foucauldian study of nineteenth-century realism. ${ }^{2}$ Miller reads Dickens as everywhere revealing both the extent to which subjects are fully and thoroughly constituted by social forces, inscribed into the social order, and the many ways in which those same subjects seek to disavow that fact through elaborate rituals of secrecy. For Miller, the rituals of secrecy are merely a ruse of power, which manages social subjects by encouraging their belief that power does not itself construct their own sense of privacy. Miller's account of modern subjectivity reveals a "structural uniformity" of character in Dickens, in the nineteenth-century novel, and throughout modern disciplinary society. ${ }^{3}$ Everyone participates in the illusion of interiority. As I have argued, however, there is a critical difference between "fallen" and protected characters in Dickens, insofar as the fallen character is denied, and denies herself, those illusions of freedom and privacy that constitute Miller's modern subject. Miller's failure to remark on this difference is ironic insofar as his own text everywhere recapitulates the Dickensian fallen subjectivity, which knows itself only as determined, which looks inward only to find an inscribed self. All the same, Miller's reading is in a deep sense true to Dickens, who himself is clearly haunted by the forms of

2. Two of the five novels chosen for individual study are by Dickens, who also figures prominently in Miller's introduction. D. A. Miller, The Novel and the Police.

3. Miller, The Novel and the Police 203. 
subjectivity he assigns to the fallen. But, as I have stressed, we need not reproduce such extreme conceptions in our theoretical approaches.

For despite its importance as an emphatic intervention into naturalizing conceptions of vice, Dickens's bleak version of fallenness remains locked within a hypostatized subject/structure opposition. It is of course desirable to have larger social analyses inform our self-conceptions; but in Dickens, impersonal forces distortedly define identities and relations. The fallen read themselves as the mere effects of larger forces, and their self-understandings terminate in an estranging third-person perspective. The pure or protected characters similarly read the fallen as the victims of larger forces, hence the many scenes in which a male protagonist stands still before a fallen, falling, or drooping woman. This posture not only thwarts the possibility for mutuality, it entrenches an atomized notion of individuality. And I am suggesting here that such a notion is recapitulated in Miller, where it appears as the pathos of confessionalism, the highlighting of the critic's own solitary self and the illusions to which he, as a thoroughly modern subject, chooses to cling.

Not all poststructuralist critics are as pessimistic as Miller. Indeed, just as John Stuart Mill and other mid-Victorians sought to protect against the anxious feelings of fatalism that accompanied the endorsement of a new social science, many poststructuralist critics, having embraced a conception of constructed subjectivity, still seek to protect themselves against those feelings of fatalism that trouble their own political and ethical commitments, at the same time that they view with profound suspicion the kind of "moral freedom" that Mill sought to justify, or the kind of wholesale social transformation that Owen envisioned. However, like the Victorian rhetoric of fallenness, itself fascinated with structures and impersonal forces, poststructuralist approaches frequently have trouble conceiving the standpoint that is assumed by subjects in a nonreifying encounter. This limitation is ironic, precisely because much poststructuralist cultural criticism takes for its topic the processes of othering, both subtle and blatant, that underwrite economies of power and inform discursive practices. Likewise, the tasks of historical and cultural recovery in the contemporary human sciences often aim to reconstruct and thereby "give voice" to the suppressed or negated experiences of historically subordinated groups, groups defined 
through hierarchies of gender, race, class, and sexuality. To take a central example, the movement of cultural studies in Britain and North America largely derives from the felt need to reconstitute the lived practices of subcultures, social groups, and variously positioned subjectivities. Indeed, in his recent survey of cultural studies, Patrick Brantlinger offers the following as the main "lesson" of cultural studies: "In order to understand ourselves, the discourses of 'the Other' - of all the others-is that which we most urgently need to hear."

Of course, throughout this study I myself have located a negative process of othering in the depictions of prostitutes and fallen women. Such a negative process, I have repeatedly asserted, is enabled and supported by a faulty and extreme conception of determined subjectivity. I suggest here that poststructuralist cultural criticism, which in many ways deeply influenced my desire to explore depictions of fallen otherness in Victorian culture, can itself end up reifying subjectivity in its more extreme constructionist formulations, thereby undermining its own normative project of overcoming repressive and disabling approaches to cultural difference. This problem has of course been recognized by many working in the field of cultural criticism, prompting reformulated approaches that emphasize "lived experience," autobiographical selfunderstanding, or the subject's own participation in its construction. Nonetheless, as I hope to show, these reformulations still fail to reconcile their appeals to reconfigured forms of social interaction with their accounts of subjectivity and selfhood. And this problem is of fundamental importance to the larger project of cultural criticism to which this book aims to contribute. For it seems to me we need to elaborate conceptions of subjectivity and social interaction that remain consistent with the normative principles that guide our practices of cultural interrogation and transformation; this consistency becomes especially important as we seek to answer the challenge that a multicultural society poses to our theoretical understandings. At the most basic level, we must forward the possibilities for mutual understanding even as we respect difference and acknowledge indeterminacy. In an attempt to contribute to such an admittedly daunting task, I elaborate and endorse a revised version of the Habermasian model of communicative action, one that can incorporate

4. Patrick Brantlinger, Crusoe's Footprints 3. 
precisely those elements of sympathetic reciprocity and indeterminate otherness that I stress in my readings of Victorian texts. ${ }^{5}$

In doing so, however, I want to examine more closely what is widely regarded as the primary impasse or, in less skeptical formulations, the constitutive tension of poststructuralist thought: the incommensurability between its epistemological stance and its political claims, between its descriptions and its prescriptions, between the pessimism of its intellect and, if not the optimism, at least the intrusiveness of its moral and political will. I want to do so to avoid suggesting any simple conflation of Victorian and contemporary debates; this is an "Afterword" precisely because it seeks to extend the consideration of questions of agency to contemporary theory. "Poststructuralism" is of course a wide and varied terrain, but the shared tenets of its several manifestations-deconstructive, psychoanalytic, Marxist, Foucauldian-form something of a generalizable paradigm. Poststructuralism in its various guises forwards a critique of humanism and the unified subject of modern liberalism, and casts Enlightenment conceptions of truth, rationality, and autonomy as at once deluded and oppressive, derivatives of a falsely universal conception of human subjectivity that in turn relies upon and enables multiple forms of power and domination. The critiques of power and domination, however, entail implicit normative claims that remain external to the overarching antifoundationalist epistemology. Ever-encroaching and self-extending power networks in Foucault, the violence of metaphysics in deconstruction, reified or suppressed otherness in cultural and literary criticism-all of these make appeal at some level to a vision of unalienated relations and undamaged forms of social life. As Habermas writes in discussing the critique of reason as it has been waged through negative dialectics, deconstruction, and genealogy,

Whether modernity is described as a constellation of life that is reified and used, or as one that is technologically manipulated, or as one that is totalitarian, rife with power, homogenized, impris-

5. Brantlinger himself concludes his survey of cultural studies with a call for a turn to the Habermasian model of communicative action; I offer, however, certain revisions of Habermas from a feminist perspective, and I provide a series of critiques of contemporary paradigms that differ from Brantlinger's. Brantlinger's is one of very few positive considerations of Habermas among literary studies. For an adaptation of the Habermasian conception of the public sphere for a feminist project, see Rita Felski, Beyond Feminist Aesthetics. 
oned-the denunciations are constantly inspired by a special sensitivity for complex injuries and subtle violations. Inscribed in this sensitivity is the picture of an undamaged intersubjectivity that the young Hegel first projected as an ethical totality. ${ }^{6}$

The same normative appeal attends poststructuralist cultural criticism, which has itself grown out of the earlier critiques of modernity. In poststructuralist criticism, this normative appeal also only fleetingly or awkwardly appears, since it is characteristically subordinated to a perspective that construes the human subject as the effect of larger forces and structures: as the point through which language speaks, as the site of unconscious disruptions, or as a position within a social grid traversed by the constitutive forces of gender, race, and class. This third-person perspectivewhat I earlier called the residual objectivism of poststructuralismrelegates morality to the status of assertion or intimation and casts into question its own viability as critique, since, as Peter Dews points out, the philosophical position of poststructuralism "assumes the foundations of the classical forms of critique to be necessarily and oppressively identitarian."

Many who subscribe to the poststructuralist paradigm dismiss the problems of grounding one's critique or being able properly to account for one's own account, either by adopting a pragmatic stance compatible with the antifoundationalist credo or by selfconsciously embracing the idea that their own critique is necessarily complicit with those forms of power it purports to "unmask. ${ }^{18}$ But the problem of political will and normative assertion has generated a more elaborate and sustained debate. Approaches to the issue take several distinct forms, though many critics and theorists employ a combination of the forms. Some theorists posit a politically efficacious resistance or disruption that is guaranteed as a systems effect, thereby avoiding the rhetoric of voluntarism. Examples of this first approach include deconstructionist intimations about the inherent subversiveness of linguistic undecidability and psychoan-

6. Jürgen Habermas, The Philosophical Discourse of Modernity 337.

7. Peter Dews, Logics of Disintegration xvi.

8. For an example of the pragmatic stance, see Nancy Fraser and Linda J. Nicholson, "Social Criticism without Philosophy"; for examples of the admission of complicity, see Miller, The Novel and the Police, and Nancy Armstrong, Desire and Domestic Fiction. 
alytic claims for the disrupting effects of the unconscious. ${ }^{9}$ Others actively embrace the tension between epistemology and politics, affirming a "double gesture" that simultaneously avows a theoretical antihumanism and a political humanism. This approach is represented by theorists who have followed Gayatri Chakravorty Spivak's endorsement of "strategic essentialism."10 Foucault's own shifts in perspective from the systemic to the local (as the site of resistances and "reverse discourses") also rely on a similarly motivated double move. ${ }^{11}$ Still others, in part out of dissatisfaction with the double gesture, have sought to articulate political strategies that derive more directly from constructionist critique; Judith Butler is a prime example, as are the proponents of various oppositional politics. ${ }^{12}$

I argue here that none of these approaches adequately theorizes the normative appeals informing poststructuralist critique; and I hope to forward the discussion of poststructuralist politics and ethics by placing the debate in dialogue with Habermas's theory of communicative action. Habermas's project calls for a turn to "intersubjectivity" as a means of overcoming the impasse between a subjectcentered paradigm and the theoretical and ethical failures of systems theories. For Habermas, the logocentrism of Western thought and the powerful instrumentality of reason are not absolute but rather constitute "a systematic foreshortening and distortion of a potential always already operative in the communicative practice of everyday life." The potential he refers to is the potential for mutual under-

9. Paul Morrison in "Paul de Man" shows how the claim of inherent subversiveness animates Derrida's defense of de Man. The politically inflected claim for the destabilizing effects of the unconscious is exemplified in the work of Jacqueline Rose, for example, Sexuality in the Field of Vision.

10. As I discuss later, Spivak has reconsidered her earlier position on strategic essentialism.

11. See Michel Foucault, The History of Sexuality 1:101. Foucault's formulations in this text, however, tend to move back and forth between a version of the first approach, whereby resistance is itself a function of systemic power, and a dual approach that shifts between the local and the systemic (see especially 92-102). Foucauldians such as Miller, who privilege the systems view, subscribe to a cynical version of the first approach: in this case resistance is a function of the system, yet it fundamentally perpetuates rather than destabilizes or transforms that system. See Miller, The Novel and the Police.

12. Judith Butler, Gender Trouble. I am here analyzing some prominent approaches within the field of cultural criticism, but my discussion cannot hope to cover the entire field of poststructuralist politics and ethics. For a useful survey that extends beyond the scope of this Afterword, see Martin Jay, "The Morals of Genealogy." 
standing "inscribed into communication in ordinary language."13 Habermas recognizes the dominance and reach of instrumental reason-his project is largely devoted to a systematic analysis of the historical conditions and social effects of that dominance-yet at the same time he wishes to retrieve an emancipatory model of communicative reason derived from a linguistic understanding of intersubjective relations. ${ }^{14}$

As I stated earlier, accounts that remain unable to mediate between the systemic and intersubjective perspectives, and that fundamentally privilege the former, ironically end up reifying subjectivity and otherness in a manner analogous to those forms of exclusion that are typically the object of critique. Habermas's announced shift from the paradigm of the philosophy of consciousness to the linguistically conceived paradigm of mutual understanding, by contrast, cogently addresses and resolves the problems generated by the impasse of poststructuralism as I outlined it above. This shift makes possible a nonmetaphysical grounding of critique by means of those very emancipatory communicative ideals that already inhere in acts of linguistic exchange. It renders explicit the ideal of undamaged intersubjectivity that the critique of systemic distortion necessarily implies and invokes. And it mediates between the prescriptive and descriptive in its employment of dialogic reciprocity as a regulative ideal that can guide political practices. It suggests, in other words, that if various forms of domination undermine, distort, or even foreclose the communicative ideal incipient in dialogical relations, then our task is not only to analyze those distortions but also to nurture the communicative ideals of recognition and respect. This is by no means to imply that such an ideal could ever be fully actualized or that "learning to listen" is an antidote adequate in and of itself to massive, structurally embedded inequalities. As Richard J. Bernstein writes,

13. Habermas, Philosophical Discourse 311.

14. See Jürgen Habermas, The Theory of Communicative Action. Habermas's work has inspired a wide range of scholars working in discourse ethics. Versions of the Habermasian call for a turn to "intersubjectivity" and dialogism have characterized important work by, among others, Seyla Benhabib, Richard J. Bernstein, and Nancy Fraser. Benhabib and Fraser have been crucial in the elaboration of feminist critiques of Habermas, and Benhabib in particular is important to the arguments I make here. See Seyla Benhabib, Critique, Norm, and Utopia and Situating the Self; Richard J. Bernstein, Beyond Objectivism and Relativism; and Nancy Fraser, Unruly Practices. 
It would be a gross distortion to imagine that we might conceive of the entire political realm organized on the principle of dialogue or conversation, considering the fragile conditions that are required for genuine dialogue and conversation. Nevertheless, if we think out what is required for such a dialogue based on mutual understanding, respect, a willingness to listen and risk one's opinions and prejudices, a mutual seeking of the correctness of what is said, we will have defined a powerful regulative ideal that can orient our practical and political lives. ${ }^{15}$

The theories of communicative reason and ethics profoundly shift the terms of the debate as they have been elaborated by the other approaches to the normative impasses of poststructuralism. The first approach is inadequate insofar as it locates subversion and transformation entirely beyond individual or collective agency. The double gesture, in calling for an oscillation between local acts of will and a systemic view of the social grid, objectifies social identities and fails to show how or why we should want to privilege certain acts of will over others. The more consistent models of subversive or oppositional politics redress problems in the other two approaches yet still lack a positive normative dimension. I argue that the Habermasian theory not only overcomes the impasses of the other approaches but also can itself be reformulated so as to accommodate less exclusively rationalistic conceptions of intersubjective reciprocity and so as to acknowledge more fully the indeterminacy of social relations. To make the case for a revised Habermasian model, I first examine in some detail the call for a "double gesture" that embraces both a theoretical antiessentialism and a "strategic essentialism." It is important to begin here because the double gesture self-consciously attempts to resolve the tension between theory and politics, and hence in certain ways might be seen as redressing the "cryptonormativism" that characterizes other approaches. ${ }^{16}$

15. Bernstein, Beyond Objectivism and Relativism 162-63.

16. I borrow the word "cryptonormative" from Habermas, who uses it to characterize Foucault's failure to maintain a merely neutral stance toward the positivity of power. Habermas, Philosophical Discourse 294. 


\section{Risks Necessary and Unnecessary}

Back in 1978, in a long and influential article about sexual difference, politics, and the cinema, Stephen Heath wrote that the project of exposing the constructed character of sexual difference need not and perhaps should not be defined in opposition to the project of reconstructing the woman's gaze or of attempting to "distinguish positively feminine elements in particular film practices." In a phrase that was to be taken up by academic cultural critics and literary theorists in the mid- to late eighties, Heath surmised that "the risk of essence may have to be taken." ${ }^{17}$ In a similar vein, Spivak began in interviews and essays in the mid-eighties to elaborate a concept of "strategic essentialism" that, from the vantage point of a deconstructive antihumanism, both justified and endorsed political uses of humanist categories such as the will, autonomy, rights, consciousness, and identity. ${ }^{18}$ Numerous poststructuralist critics and theorists-aligned with feminism, cultural studies, and gay and lesbian studies - have in turn advocated some form of alliance between constructionism and essentialism, or between antihumanist theory and humanist claims and practices. ${ }^{19}$ The double gesture that characterizes this paradoxical practice accepts and renders explicit the poststructuralist tension between theory and politics. It also seeks to redress a perceived problem of agency: rather than locating subversion and transformation entirely beyond individual or collective agency, it obtrusively insists on a kind of voluntarism, though one that remains informed by the antifoundationalist critique of the will.

An understanding of strategic essentialism cannot be gained simply from analyzing the origins of the term and its subsequent citations, for there are many manifestations of a similarly motivated double gesture that do not employ the term. In fact, within feminism, a version of strategic essentialism began to appear along with the

17. Stephen Heath, "Difference" 99.

18. See Gayatri Chakravorty Spivak, "Criticism, Feminism, and the Institution," "Strategy, Identity, Writing," and "Subaltern Studies."

19. For endorsements and elaborations of reconsidered understandings of essentialism, some of them explicitly endorsing a double gesture similar to Spivak's, see Diana Fuss, Essentially Speaking; Ann Snitow, "A Gender Diary"; Teresa de Lauretis, Technologies of Gender 26, and "Upping the Anti (sic) in Feminist Theory"; Paul Smith, Discerning the Subject; Biddy Martin, "Feminism, Criticism, and Foucault"; Rosa Braidotti, "The Politics of Ontological Difference"; Margaret Whitford, Luce Irigaray. 
first sympathetic appropriations of poststructuralist thought. In Sexual/Textual Politics, for example, Toril Moi endorses Julia Kristeva's " 'deconstructed' form of feminism" but warns at the same time that "it still remains politically essential for feminists to defend women as women in order to counteract the patriarchal oppression that precisely despises women as women. ${ }^{\prime 20}$ Moi does not make clear precisely what she means by "as women"; rhetorically, she enacts the very affirmation of unified identity for which the statement calls. One might also view the looseness of her formulation as a deliberate eclipsing of theoretical precision by political demand.

Moi's position exemplifies what has become a primary version of strategic essentialism, that is, the argument that a political pragmatism must accompany poststructuralist strategies of demystification and critique. Within this framework, however, essentialist categories are often cast as imperative in more than a narrowly pragmatic way. It isn't simply the case that we need categories such as rights and the subject of those rights in order to achieve distinct political goals; we also need myths of community and identity in order to counter dominant ideologies and underwrite collective forms of political practice. The more narrow approach assumes simply that we need to work within the existing system; the broader one makes a more fundamental claim about the role of myth and identity in human praxis. It makes a claim about a common human need (though usually not so baldly as that). As Ann Snitow writes, "Whatever the issue, feminists have gained a great deal by saying, 'We are "women," and this is what "women" want.' This belief in some ground of shared experience is the social basis from which any sustained political struggle must come. ${ }^{\prime 21}$

The argument for the political necessity of identity thinking thus claims that we must deliberately choose certain strategies whose abandonment in the name of poststructuralist rigor would be grossly misguided. Another version of strategic essentialism-or sometimes just another moment within a strategic essentialism argument-concentrates not so much on the future as on the past, arguing that, despite itself, essentialism has produced progressive political effects

20. Toril Moi, Sexual/Textual Politics 13. Moi reelaborates and further complicates this position in "Feminism, Postmodernism, and Style," arguing that we must "live out" the contradictions of not a double but a treble feminism, one that simultaneously affirms equality, difference, and deconstruction.

21. Snitow, "A Gender Diary" 12. 
in the past. More a practice of reading than a plan of action, this approach revises and recuperates not only the past but also what are too often quickly dismissed as anachronistic or naive textual practices in the present. Spivak's approach to the Subaltern Studies project, a postcolonial historical reconstruction of Indian colonial "experience," exemplifies this particular facet of strategic essentialism. While Spivak sees an important constructionist emphasis in much of the work of these historians, she seeks also to explain and recuperate what her Western antihumanist training has caused her to view with considerable suspicion: an investment in the will, consciousness, and effective agency of the subaltern, a commitment to reconstructing the lost, negated, or covered-over experience of Indian colonial subjects. She accounts for these essentialist emphases by positing an unavoidable asymmetry between her work and the work of the historians, one constituted through the displacing axis of the "international division of labor": "The discourse of the unified consciousness of the subaltern must inhabit the strategy of these historians, even as the discourse of the micrologized or situated subject must mark that of antihumanists on the other side of the international division of labor." 22 Spivak not only explains but also privileges the work of these historians: by casting the subaltern as "the subject of his own history," the Subaltern Studies project importantly reveals "the limits of the critique of humanism as produced in the west." ${ }^{\prime 23}$ What Spivak means here is that the critique of humanism remains blind to the ways in which the reconstruction of subjectivity, experience, and identity is of vital importance to groups who have been colonized.

Spivak's reading thus seems to grant the Subaltern Studies project a kind of autonomous critical function, insofar as she credits the historians with revealing the limits of antihumanism. Yet she simultaneously feels compelled to rescue the project from its own naiveté by reading it as a "strategic use of positivist essentialism in a scrupulously visible political interest. ${ }^{\prime 24}$ Strangely, this formulation retains the notion of a strategy in a case where the effects seem not to have been calculated from a thoroughgoing poststructuralist vantage point. It's one thing to say that the historians' emphasis on

22. Spivak, "Subaltern Studies" 210.

23. Spivak, "Subaltern Studies" 209; my emphasis.

24. Spivak, "Subaltern Studies" 205. 
humanist categories has a corrective effect on poststructuralist paradigms; that places their work in productive dialogue with Western deconstruction. But it's quite another thing to reinscribe their operative concepts as strategies, when they simply don't evince any such attitude toward them. ${ }^{25}$ The strategy here lies in the critic's reading of the historians, not with the historians themselves. In a similar way, Diana Fuss recasts Luce Irigaray's essentialist language as an intentional strategy: "The point, for Irigaray, of defining women from an essentialist standpoint is not to imprison women within their bodies but to rescue them from enculturating definitions by men. ${ }^{26}$ Essentialism here becomes a brilliantly conceived escape from oppressive constructions, or constructionism tout court. That such an escape is within her own terms necessarily deluded does not trouble Fuss, for she thinks it does political good to "believe" otherwise. $^{27}$

Thus far I have laid out two different approaches to essentialism. The first, the politically pragmatic approach, endorses deliberate appropriations of essentialist and humanist categories: it is anticipatory and voluntaristic. The second, the recuperative, retroactive version, rereads and revises what have hitherto been dismissed as failed or faulty practices. It is backward looking rather than forward looking, a way of reading rather than a political prescription. The third and final approach to essentialism that I examine here paradoxically modifies the notion of intentional strategy altogether; it insists instead that essentialism is entirely unavoidable and hence something we must affirm and use. I first examine the way this

25. Her indication at one point that this strategy is "partially unwitting" highlights rather than resolves this issue. Spivak, "Subaltern Studies" 207.

26. Fuss, Essentially Speaking 61.

27. De Lauretis has made the most encompassing feminist reinscription of essentialism to date in "Upping the Anti (sic) in Feminist Theory." She argues, invoking Locke, that the essence appealed to in the writings of many so-called essentialists is a nominal and not a real essence; it is, in other words, a constructed essence. "It is a totality of qualities, properties, and attributes that such feminists define, envisage, or enact for themselves.... This is more a project, then, than a description of existent reality; it is an admittedly feminist project of 're-vision,' where the specifications feminist and re-vision already signal its historical location, even as the (re)vision projects itself outward geographically and temporally (universally) to recover the past and claim the future" (257). De Lauretis thus overcomes the tension between essentialism and constructionism by recasting the former as a version of the latter. Such an argument, however, involves a rather drastic reduction of cultural and radical feminisms, and ultimately has the effect of projecting a false unity on the diverse and contested field of feminism. 
argument appears in Spivak's work and then move on to more recent feminist assertions that some form of double gesture is in fact inescapable. ${ }^{28}$

For Spivak, whose political criticism is strongly influenced by deconstruction, essentialism is not something that we could ever jettison or have done with, since it is a function of language-or logocentrism-itself. She makes a representative statement in a 1986 interview: "Since one cannot not be an essentialist, why not look at the ways in which one is essentialist, carve out a representative essentialist position, and then do politics according to the old rules whilst remembering the dangers in this? That's the thing deconstruction gives us; an awareness that what we are obliged to do, and must do scrupulously, in the long run is not OK." ${ }^{29}$ Not OK, because essentialism enacts the violence of metaphysics generally and a host of exclusions historically, exclusions primarily of race and gender. Thus, although deconstructive critique must be supplemented by political practice, practice itself must be continually corrected by theory. Or, as Spivak puts it, not only does practice norm theory, but "theory always norms practice."

While Spivak argues for the necessity of essentialism from within the paradigm of deconstruction, others such as Ann Snitow and Denise Riley have argued, in somewhat different terms, that the double gesture is simply constitutive of the history of feminism, or of feminism itself. In the opening paragraph of "Am I That Name?": Feminism and the Category of "Women" in History, Riley states, "Both a concentration on and a refusal of the identity of 'women' are essential to feminism. This its history makes plain. ${ }^{131}$ In "A Gender Diary," Snitow offers a similar argument: "Feminism is inevitably a mixed form, requiring in its very nature such inconsistencies.... A common divide keeps forming in both feminist thought and action between the need to build the identity 'woman' and give it solid political meaning and the need to tear down the category 'woman' and dismantle its all-too-solid history." ${ }^{\prime 32}$ Snitow's essay carefully works through the way this divide informs a number of classic de-

28. Again, as should be clear from the reinvocation of Spivak, more than one version of strategic essentialism can appear within a single argument.

29. Spivak, "Strategy, Identity, Writing" 45.

30. Spivak, "Strategy, Identity, Writing" 44.

31. Denise Riley, "Am I That Name?" 1.

32. Snitow, "A Gender Diary" 9. 
bates within feminism-the essentialism/constructionism debate, the equality/difference debate, and the tension between cultural feminism and poststructuralism. Snitow argues that the divide cannot be overcome through thought alone and that it will only be overcome in a historical process. On this basis, she dismisses any attempt at what she calls "third course thinking" and asserts instead that " 'embracing the paradox' is just what feminism cannot choose but do." ${ }^{\prime 3}$ I suggest that Snitow fails to make a crucial distinction here. Recognizing the importance of a divide within the history of feminism, and understanding the powerful ways that divide informs the contemporary moment, does not mean that one is obliged to embrace that divide theoretically. Indeed, transmuting the historical debate into a theoretical postulate generates a series of problems, both practical and theoretical. At the least, a certain irony attends this position, insofar as it aims to get beyond debate and disagreement by insisting that we all affirm a contradiction. But as we shall see, the call to "embrace the paradox" is itself elaborated from, and fundamentally privileges, the poststructuralist position. In some ways this position reinscribes the problem of rescue and recuperation that marks the revisionist approach to essentialism. The recuperative stance harbors within itself, however, a more fundamental problem. By associating essentialism with practice and antiessentialism with an ultimate theoretical truth, the articulation of strategic essentialism generates a theory/practice split. In turning to Habermas, I will argue for a conception of theory that can render explicit, rather than undermine, the norms and self-understandings that are internal to practice. That is, theory need not be other than (and superior to) practice; ideally, it is practice itself as self-reflexive.

To further elaborate my critique of the double gesture, however, I must return to Spivak, who made the apparently even-handed claim that practice norms theory and theory norms practice, that each corrects the excesses or blindnesses of the other. In her reading of the Subaltern Studies project, as we have seen, Spivak argues for the importance of essentialist categories insofar as they point up a "limit" in the Western critique of humanism. But two things then crucially modify, if not altogether undermine, that point. First, as I

33. Snitow, "A Gender Diary" 19. Snitow is here citing-and criticizing-Linda Alcoff's attempt to transcend the paradox in "Cultural Feminism versus PostStructuralism." For another argument precisely featuring and privileging feminism's elaboration of doubled strategies, see Smith, Discerning the Subject. 
mention above, Spivak feels compelled to rescue the historians' practice by designating it as a strategy. Second, this retrieval is complemented by Spivak's own antihumanist reading of the subaltern's "identity" as "no more than a theoretical fiction to entitle the project of reading": "What had seemed the historical predicament of the colonial subaltern can be made to become the allegory of the predicament of all thought, all deliberative consciousness, though the elite profess otherwise. ${ }^{\prime 34}$ This formulation should sound familiar to feminists, insofar as Lacanian feminism reads precisely in this fashion. The scapegoated feminine predicament reveals the truth of the whole: nobody has the phallus. Here, the negated subaltern reveals the truth of the whole: nobody has autonomous deliberative consciousness. In my view, however, to read historically disempowered or negated subject-positions as figures for an abstractly decentered subjectivity is to distort our understanding of both the decentered subject and the condition of specific oppressed groups. More important, Spivak generates a false dualism between a higher theoretical truth-the truth of decentered subjectivity-and what ultimately must then be seen as an enabling practical lie. That is, her conception of a strategic essentialism that both guarantees practice and then obligingly acts as a target for a knowing antihumanism ultimately works to disarticulate practice from theory, subordinating the former to the latter.

The idea that practice only works through what are ultimately dangerous fictions diminishes the extent to which the critique of naturalized identities can itself inform political practice. In terms less ominous than Spivak's, for example, Snitow nonetheless similarly suggests that those engaging in political activism are required to foster a forgetfulness of the kind of constructionist critique that led them to understand the workings of power in the first place:

We begin: The category "woman" is a fiction; then poststructuralism suggests ways in which human beings live by fictions; then, in its turn, activism requires of feminists that we elaborate the fiction "woman" as if she were not a provisional invention at all but a person we know well, one in need of obvious rights and powers. Activism and theory weave together here, working on what remains the same basic cloth, the stuff of feminism. ${ }^{35}$

34. Spivak, "Subaltern Studies" 204.

35. Snitow, "A Gender Diary" 19. 
The problem I have with this formulation lies in the way constructionism belongs to poststructuralism, while activism requires the bracketing of constructionist critique (pace the weaving metaphor) ${ }^{36}$ In a refusal of these kinds of double gestures, some cultural critics have insisted that we derive our politics more directly from constructionist critique. For example, Judith Butler argues for a feminist politics "that will take the variable construction of identity as both a methodological and normative prerequisite, if not a political goal. ${ }^{\prime \prime 37}$ For Butler, the affirmation of unified identity is not a political necessity; on the contrary, the disruption of naturalized conceptions of identity should serve as the model for political practice as such. ${ }^{38}$ Butler thus aims to reconcile the normative and the theoretical and does not insist on their irreducible opposition.

Yet Butler's theory remains limited insofar as it fails to account sufficiently for the political ideals and values that inform progressive practice, ones that extend beyond the recognition of constructedness. For Butler, the point is not simply to show that all subjectivity is constructed but also to show that it is constructed within a dominant and oppressive heterosexual matrix. And in characterizing the heterosexual matrix as dominant and oppressive, she means to emphasize, one can only assume, its failure to recognize and respect other sexualities and subjective practices. But this is a normative claim that only cryptically informs her account. Subverting identity constitutes the methodology and the goal of feminist political practice; recognition and respect inform the discussion but are not given theoretical primacy. Butler introduces the ideas of coalition and dialogue, but only to argue against the possibility of formulating any notion of solidarity, which she in an unwarranted move equates with unity: "Despite the clearly democratizing impulse that motivates coalition building, the coalitional theorist can inadvertently reinsert herself as sovereign of the process by trying to assert an ideal form for coalitional structures in advance, one that will effec-

36. Snitow is actually careful elsewhere not to generate an opposition like this; it is interesting that it emerges within her section on poststructuralism.

37. Butler, Gender Trouble 5.

38. Other critics have avoided strategic essentialist arguments by endorsing a model of coalition based on a shared opposition to dominant power matrices. See Lisa Duggan, "Making It Perfectly Queer"; Chandra Talpade Mohanty, "Cartographies of Struggle." These approaches importantly argue that we can articulate political practices that integrate constructionist critique. 
tively guarantee unity as the outcome. ${ }^{\prime 39}$ But there's a difference between giving theoretical explicitness to tacitly supposed intersubjective ideals and decreeing what "unity" will be. While I am entirely in accord with Butler's idea that we should expect "divergence, breakage, splinter, and fragmentation" as part of the dialogical process of democratization, I think that she makes this point only to swerve away from giving theoretical prominence to the intersubjective ideals that inform this very point. ${ }^{40}$

Spivak's own reconsiderations on the topic of strategic essentialism revealingly devolve on the issue of dialogue and intersubjectivity. In an interview with Ellen Rooney for the journal Differences, Spivak expresses surprise as well as regret at the way strategic essentialism has been so widely heralded as a solution to theory's political impasses, suggesting that we must shift toward a new terrain, that of "building for difference." ${ }^{\prime 11}$ Over the course of the questioning, Spivak manifests a repeated impatience with the very term essentialism and with the attempt to refine a theory about it. Arguing that we must talk of deconstructive practice in more "mundane" terms, she calls for "a sort of deconstructive homeopathy, a deconstructing of identity by identities. ${ }^{\prime 42}$ Partly Spivak is answering the charge that she talks too much about herself:

I believe that the way to counter the authority of either objective, disinterested positioning or the attitude of there being no author (and these two opposed positions legitimize each other) is by thinking of oneself as an example of certain kinds of historical, psychosexual narratives that one must in fact use, however micrologically, in order to do deontological work in the humanities. When one represents oneself in such a way, it becomes, curiously enough, a deidentification of oneself, a claiming of an identity from a text that comes from somewhere else.... To an extent, the way in which one conceives of oneself as representative or as an example of something is this awareness that what is one's own, supposedly, what is proper to one, has a history. That history is unmotivated but not capricious and is larger in outline than we are, and I think this is quite different from the idea of talking about oneself. ${ }^{43}$

39. Butler, Gender Trouble 14.

40. Butler, Gender Trouble 14.

41. Gayatri Chakravorty Spivak, "In a Word" 128.

42. Spivak, "In a Word" 130.

43. Spivak, "In a Word" 130-31. 
A self-reflexive form of autobiographical historicizing thus enables productive deidentifications without the pretense of a rigid antiessentialism: "Being obliged to graph one's bio is very different from the attitude of claiming anti-essentialism. ${ }^{\prime 44}$ In the interview Spivak thus reelaborates the concept of a necessary essentialism, one that, if accompanied by a "persistent critique," will prompt efficacious (homeopathic) deidentifications, thereby successfully curing people of the impulse to naturalize their histories and identities. ${ }^{45}$ We are back, then, to a more basic claim about deconstruction's capacity for demythologizing critique, and hence back to a claim about the political efficacy of deconstruction. Yet despite the holistic connotations of the homeopathic metaphor, the form of the double gesture is still discernible as the internal oscillation, within the individual, between identification and deidentification. All the same, Spivak has abandoned the sharp opposition between strategic local practices and a demystifying theoretical deconstruction practiced "elsewhere"; and there is quite a difference between a persistent self-critique modeled on hermeneutic selfawareness (which her reformulation suggests) and an endorsement of decisionist essentializing.

Spivak's reconsiderations thus only partly recapitulate her earlier position. What I am more interested in, however, is the extent to which the category of otherness seems to have prompted her impulse to revise. That is, a redirective toward dialogical relations frequently accompanies Spivak's admission of the earlier argument's inadequacy. For example, in an attempt to derail what she takes to be a misguided emphasis on the theoretical question of a pristine antiessentialism, she introduces the new goal of "building for difference." And at the very end of the interview there is a sudden insistence on the importance of transactions with an audience:

Many of the changes I've made in my position are because the audience has become a co-investigator and I've realized what it is to have an audience. You know what I'm saying? An audience is part of one. An audience shows us something. Well, that is the transaction, you know, it's a responsibility to the other, giving it 
faces. It's not ... I don't see this de-essentializing particularly, but really deconstructing the binary opposition between investigator and audience. ${ }^{46}$

When one co-investigates by inviting an audience to respond, then "positionality is shared with it." ${ }^{\text {47 }}$

The realization of what it is to have an audience has disrupted and rendered inadequate Spivak's earlier position and in fact prompted her toward a conception of "shared positionality." I suggest, however, that "shared positionality" can function only as a threshold concept in Spivak's overall account, an account that still subordinates intersubjectivity to a systems perspective. Spivak makes an appeal to mutual understanding, but the form of selfunderstanding that underlies mutual understanding is conceived exclusively from a systemic perspective. In recognizing one's positionality, in "thinking of oneself as an example of certain kinds of historical, psycho-sexual narratives," one undergoes the salutary process of deidentification. In sharing positionality, presumably, one recognizes the other as similarly constructed, as equally an example of certain larger narratives without which self-representation remains impossible, and as equally capable of homeopathic deidentifications. One could presumably undergo a dialogue in which such forms of self-understanding were exchanged, mutually prompted, and critically examined. However, it still remains the case that such a conception of intersubjectivity is radically truncated insofar as it is routed only through the systemic perspective. The form of selfunderstanding embraced is one whereby the subject sees himself or herself not as constituted through intersubjective relations but rather as a member of an atomized, post hoc "community" of systems effects.

In response to the potentially reified conceptions of subjectivity that derive from a too-atomized version of positionality, some critics have focused instead on the individual as the site of heterogeneous, multiple identities. Thus, for example, as a white lesbian workingclass student, or as a black middle-class heterosexual law professor, one becomes the site of intersecting and often conflicting positions that one is always "negotiating." Yet as Diana Fuss argues, risks of

46. Spivak, "In a Word" 153.

47. Spivak, "In a Word" 153. 
essentialism and reification inhabit both singular and multiple conceptions of positionality, insofar as "the essentialism in 'antiessentialism' inheres in the notion of place or positionality. ${ }^{\prime 48}$ Fuss herself endorses the Lacanian conception of identity as radically destabilizing, as at once necessary and impossible, "alienated and fictitious." ${ }^{\prime 49}$ According to Fuss, a nonpsychoanalytic conception of constructed identity, whether singular or multiple, does not acknowledge the "subversive and destabilizing potential of the Unconscious" and engages in an unanxious taxonomy of "identifiable and unitary," even if ultimately conflicting, notions of identity. ${ }^{50}$

Unlike Fuss, I am less concerned here with the charge that social constructionist discourse can lend itself to fixed conceptions of identity than I am with the objectivism, or systems perspective, that often dominates the elaboration of subject positionality. Indeed, the notion of subject-positions ironically partakes of an inverted Cartesianism: the various anti-cogitos of poststructuralism simply define the human subject as res extensa rather than res cogitans and thereby reinstate a curiously scientistic model. Such a dualistic framework precludes the possibility of an intersubjective perspective that would define the human subject not as purely autonomous and selfpresent, nor as a mere place on intersecting grids, but rather as constituted through its ongoing relations to others as they are mediated by language, social systems, and history. The Lacanian paradigm of split subjectivity, while it may avoid the essentialism of place, does not further such an understanding but rather insists on an internally destabilized or "precarious" subject. Moreover, that internal destabilization is the product of a dualistic subject-structure model. Coherent self-identity is disrupted by a systemic force: the unconscious as the symbolic order or what Dews calls the "transindividual dimension of language." ${ }^{51}$ For Lacan, language remains in crucial ways an interruptive and not an enabling medium.

It is certainly true that many poststructuralist accounts have attempted to forward nonmechanistic theories of subject constitution, particularly by emphasizing that subjects perform, enact, or participate in their own constructions. A kind of participation does, for example, emerge in Foucault's accounts of constructed subjectivity,

48. Fuss, Essentially Speaking 29.

49. Fuss, Essentially Speaking 102.

50. Fuss, Essentially Speaking 105, 103. This emphasis exists in some tension with her arguments in favor of strategic essentialism.

51. Dews, Logics of Disintegration 83. 
but it subordinates intersubjective relations to the workings of a systemic form of power. In his very last works on the classical period in Greece, Foucault significantly shifted his attention precisely to ethical relations; however, the highly influential Discipline and Punish and The History of Sexuality, Volume I focus overwhelmingly on the singular subject's participation in his or her own construction, the various means by which modern individuals "willingly" internalize the workings of disciplinary power. Spivak's own conception of "being obliged to graph one's bio" follows in the wake of this project to understand the drama of subject constitution, as does Judith Butler's emphasis on the potential for adopting a parodic relation toward the construction one is "in." To conceive of the subject as a participant in its own constructions, however, is not the same as conceiving of the subject as a participant in social communities. ${ }^{52}$ The self-disciplining, self-inscribing, or self-parodic subject is one whose most fundamental relation is to the system and not to other subjects. Indeed, Foucauldian as well as Lacanian models fundamentally tend to read intersubjective relations as displaced confrontations between the subject and the system. The Lacanian rewriting of the oedipal scenario as a confrontation with the Law partakes of this displacement, as does the Foucauldian account of the Panopticon and the self-disciplining subject. In the Panopticon, which Foucault presents as the model of modern disciplinary society, the gaze of the concrete other becomes a mere lieutenant for a structure of anonymous and global surveillance.

Insofar as these forms of dramatizing subjectivity reduce the participatory to the systemic, they only partially describe the social world. We can certainly trace the historical and social determinants of this self-alienating mode of apprehension, which undeniably forms a part of modern self-understandings and powerfully informs the various modernist and postmodernist aesthetics. I suggest, however, that we have no obligation to reproduce this self-alienating mode as an absolute fact about the social world or modern history. The systemic anti-cogito that characterizes the poststructuralist sensibility ("The system thinks me, therefore I am not") produces an utterly atomized social field, one that precludes entering into the

52. Foucault's concept of reverse discourses would be a cogent counterexample, since these are waged by, and on behalf of, discursive groups. Foucault, History of Sexuality 1:101. 
standpoint that is assumed by subjects in nonreifying encounters. But such dominant theoretical approaches can be challenged and reconceived.

\section{Intersubjectivity: Reconceiving the Subject}

The theory of communicative action enables us to resolve the most problematic aspects of those arguments that resort to cryptonormativism or a paradoxical double gesture. It gives due prominence to the intersubjective ideals that inform critiques of othering and calls to respect differences. The accounts I discussed in the previous section fail to mediate between the systems perspective and the perspective of intersubjective and transformative praxis. In the case of the double gesture, political and theoretical practice are fundamentally irreconcilable. In the case of those more consistent accounts that attempt to derive practice from poststructuralist theory, accounts of dialogical practice and intersubjective relations are refracted through a systems perspective.

Habermas's approach can advance the debate over the politics of poststructuralism only if it is significantly revised in a less rationalistic and formalistic direction. But the conception of communicative reason is of vital importance for any theory that seeks to advance and justify democratic ideals. Habermas's account of the relations of reciprocity and recognition that are presupposed in any action oriented toward reaching understanding disallows the radical rupture between ethics and epistemology, and between practice and theory, in much poststructuralist and postmodern thought. By bringing to light those aspects of our intersubjective relations that are constituted communicatively, Habermas articulates a discourse ethics. This discourse ethics insists that the higher level of argumentation required in any self-reflexive democratic process is an extension of the more primary mode of action that is oriented toward reaching understanding. Thus, Habermas's theory enjoins us to see in our politics or ethics those regulative ideals of recognition and respect that are already presupposed in ordinary communication, presupposed even as they are simultaneously thwarted and distorted by social hierarchies and systemic domination. For Habermas, an ethics of discourse requires that norms be validated through a 
procedure of public argumentation among all those who are affected; only those norms that produce a consensus can be said to be valid.

In Habermas's account, there is thus a dialectical and not an incommensurable relation between the systemic and the intersubjective perspectives, and between the theory and the practice. The intersubjective ideal internally prompts systemic critique, and the concept of communicative reason underlies critique's claim to emancipatory and transformative potential. Thus, even though Habermas wishes to redeem a normative conception of reason and of understanding, his project must be recognized as equally devoted to uncovering the many forces and structures that thwart the ideal speech situation. ${ }^{53}$ Habermas sees democratic possibilities as endangered not simply by faulty theoretical models that deny communicative reason but also more directly by social and historical conditions that disable reciprocal relations. In order to counter the development of industrial capitalism and its attendant structures of bureaucracy and "rationalization," we must emphasize and nurture those procedures and modes of interaction that are most conducive to the communicative ideal.

In Habermas's theory, then, our status as subjects who are constituted through intersubjective relations is preserved, yet also placed in productive dialogue with an understanding of larger systems and histories. The Habermasian foregrounding of an intersubjective ideal emphatically does not mean that we abandon systemic analyses of the social world in favor of a celebratory, local insistence on community, human interrelatedness, or friendly conversation. ${ }^{54}$ We can ensure proper democratic processes only if we understand and engage those forces, both historical and structural, that determine the social world and powerfully condition what our capacities and arenas for action will be. The systemic perspective not only

53. Many fault Habermas and his followers for too naive a conception of consensus, for engaging in a form of wishful thinking. Such a complaint often fails to register the fact that Habermas is redressing an overemphasis on dissensus in postmodernist theory as well as in the Frankfurt School's failure to conceptualize noninstrumental forms of reason. Hence, his account necessarily places a very strong stress on mutual understanding.

54. My reading of Elizabeth Gaskell might be summoned to clarify this distinction, insofar as she on the one hand exhibits a myopic, mystified intersubjective ideal (through her endorsements of domestic communing and maternity) and on the other manages, at the ending of North and South, to forward a transformative model of participatory action that is more widely public, socially conscious, and self-reflective. 
allows us to understand the structurally embedded inequities that distort human interaction but also can itself meaningfully inform an intersubjective relation, insofar as it allows us more fully to understand another's history and social situatedness. ${ }^{55}$ It is practice itself, however, that prompts the move to the systemic theoretical perspective; and theory has done its work properly only if its account enables a reconfiguring of lived intersubjective relations.

As I mentioned earlier, the need to integrate a participatory or first-person perspective into cultural criticism has made itself felt in several ways in recent years. In a crucial sense, the attempt to mediate the tension between structural and "lived" accounts has defined the field of cultural studies. As Richard Johnson has written, cultural studies "is about the historical forms of consciousness or subjectivity, or the subjective forms we live by, or, in a rather perilous compression, perhaps a reduction, the subjective side of social relations. ${ }^{156}$ For Johnson as well as for Stuart Hall, cultural studies is always concerned both to use and to modify structuralist accounts. Likewise, much of the most important work being done in gender studies, postcolonialism, and gay and lesbian theory centers precisely on the reconstruction of experience in light of constructionist and poststructuralist critique. These cultural analyses involve subtle dialectical understandings of the relation between structural positions and subjective experience. ${ }^{57}$ Such approaches, insofar as they aim to mediate between systemic and lived perspectives, share an affinity with the dialectical model I'm endorsing here; and they certainly redress the dominance of the systemic perspective that I earlier criticized. However, what the theory of communicative reason would contribute to these approaches is a more explicit and integral normative self-understanding.

If the theory of communicative reason remains central to any consistent elaboration of a democratic or plural politics, it still, as I have suggested, stands in need of substantial revisions if it is to answer adequately to the complex indeterminacies of the social world and

55. Allowing the systemic perspective to "meaningfully inform" the intersubjective relation is not the same as asking that it define that relation, as in the case of Spivak's "shared positionality," a concept I criticized earlier.

56. Richard Johnson, "What Is Cultural Studies Anyway?" 43.

57. See Teresa de Lauretis, Alice Doesn't and Technologies of Gender; Biddy Martin and Chandra Talpade Mohanty, "Feminist Politics"; Linda Alcoff, "Cultural Feminism versus Post-Structuralism"; Biddy Martin, "Lesbian Identity and Autobiographical Difference[s]"; Mohanty, "Cartographies of Struggle." 
to the inseparability of feeling from action oriented toward reaching understanding. As Seyla Benhabib's feminist critique of Habermas has shown, an elaboration of affective interaction can significantly deepen the concept of mutual understanding. As part of a larger analysis of modern theories of justice and moral development, Benhabib argues that Habermas's account is elaborated only from the perspective of the "generalized" and not from that of the "concrete" other. Consequently, Habermas fails to recognize the affective specificity of reciprocal recognition, which in turn provides the basis for the principles of need as opposed to justice. As Benhabib writes, "Human situations are perspectival, and to appreciate such perspectives involves empathy, imagination, and solidarity."

Benhabib insists on the equal but separate importance of the perspectives of generalized and concrete otherness. The perspective of the generalized other serves as the basis for a principle of equality; and the perspective of the concrete other introduces the more concretely realized ethical principles of care, friendship, empathy, solidarity, and intimacy. Benhabib's account thus redresses the overemphasis on reason in the Habermasian ideal of mutual understanding. Concerned as he is to rescue reason from its detractors, Habermas does not acknowledge the extent to which the norms of mutual understanding and reciprocal recognition are internally dependent on empathy and compassion.

Habermas has met these criticisms only partway, and with an underlying recalcitrance. He acknowledges the importance of empathy to the procedure of roletaking, but thereby its importance is admitted only in the application, and not in the universal justification, of procedural ethics. ${ }^{59}$ Habermas argues that once we move historically from a traditional to a rationalized lifeworld, we can abstract questions of justice from questions of the good life. For Habermas, it is only the former that constitute the proper domain of moral theory; questions of the good life, by contrast, remain imbued with particularity and relativity-they cannot be justified, only adjudicated. Such an overly formalistic and Kantian approach to ethical theory (only seemingly tempered by Hegelian historicizing) ultimately creates an artificial rupture between questions of

58. Benhabib, Critique, Norm, and Utopia 349; also see Seyla Benhabib, Situating the Self chap. 5 .

59. Jürgen Habermas, Moral Consciousness and Communicative Action 182. 
justice, which for Habermas can be universalized, and questions of the good life, which "are accessible to rational discussion only within the horizon of a concrete historical form of life or an individual life style. ${ }^{\prime \prime 0}$ In a subsidiary move, Habermas relegates nonrational dimensions of intersubjectivity to the realm of the concrete and protects the norm of mutual understanding from any affective resonances or disruptions. Such limiting abstractions must be abandoned in favor of an approach that fully integrates particularity and affect into the norm of mutual understanding.

In response to those moral theorists who argue that an ethics of responsibility or care must accompany an ethics of justice, Habermas has claimed that the only universally justifiable complement to the perspective of justice is solidarity, and not benevolence, care, or responsibility. Although the justification of solidarity may appear to integrate an affective dimension into the theory, it turns out to refer merely to the necessary maintenance of our life as shared: the principle of solidarity "is rooted in the realization that each person must take responsibility for the other because as consociates all must have an interest in the integrity of their shared life context in the same way. ${ }^{\prime \prime 1}$ The principle of solidarity thus does not refer to the irreducible affective dimensions of our interactions with others but rather conceives of responsibility toward others as an acknowledgment that we must maintain the webs of relation that constitute our social world. But there is no reason why the norm of mutual understanding cannot be amplified so as to embrace the affective forms that accompany and enable recognition and respect. Indeed, to fail to do so is to truncate the conception of intersubjectivity that underlies systemic critique. Here Habermas himself generates distortions that issue in part, one can only surmise, out of blindness to his own biases of gender and culture.

In his attempt to further substantiate his theory of moral justification through appeal to theories in developmental sciences, Habermas has also undermined the more radical implications of his shift from a subject-centered to a communicative paradigm. Of vital importance in the theory of communicative action is the conception of the subject as intersubjectively decentered and inherently rela-

6o. Habermas, Moral Consciousness 178.

61. Jürgen Habermas, "Justice and Solidarity" 47. 
tional. ${ }^{62}$ Yet in my view Habermas's infatuation with developmental sciences both reflects and reinforces a too-stable conception of individual identity. I think we need to accentuate and further elaborate the ways in which the intersubjective relation itself works against the rigidities of identity thinking, and this despite the seeming stability invoked by the norm of "reaching understanding." As Benhabib has argued, the true negation of identity logic resides precisely in our relation to the other:

The true negation of identity logic would imply a relation to an "other" who could at every point remind the self that it was not a mere projection or extension of the self, but an independent being, another self. The limits of the compulsion to identity are revealed when the object of identification is itself capable of acting in such a way as to differentiate between identity and difference, between self and other. If identity logic is the attempt to blur limits and boundaries, then those limits can be reestablished via the act of an other self who is capable of rejecting the narcissistic self-extension of the other. The true negation of identity logic would be an epistemological relation in which the object could not be subsumed under the cognitive categories of the self without that it-the object-could also regard these categories as adequate to capture its own difference and integrity. Identity logic can only be stopped when difference and differentiation are internal to the very selfidentification of the epistemological object and subject, and this is only the case when our object is another subject or self. ${ }^{63}$

The norms embedded in the speech act need not, and indeed should not, translate into an unproblematic exchange of self-identical meanings by two placeholding consciousnesses. Indeed, as Dews has argued in his analysis of Habermas's conceptions of intersubjectivity, the ideal of reaching understanding is required precisely because of the "constitutive tension of linguistic intersubjectivity," a tension that exists "even in the absence of structural inequalities of power": "Communication is not simply a matter of the transferral of identical meanings from one consciousness to another, but involves the si-

62. See Drucilla Cornell, "Toward a Modern/Postmodern Reconstruction of Ethics" 299, for an eloquent description of subjectivity as intersubjectively decentered.

63. Benhabib, Critique, Norm, and Utopia 221. 
multaneous maintenance of the distinct identities of-in other words: the non-identity between-the partners in communication. This non-identity cannot fail to enter into the interpretation of meaning." ${ }^{64}$

Habermas's primary emphasis on the principle of justice (as that which enforces relations of equality) and his reconstruction of moral stages of development have tended to diminish the profound importance of intersubjective tension and social plurality, even as procedural ethics remains in the service of adjudicating between concrete individual and collective constituencies. He also risks installing a too-unified conception of subjectivity and social identity. I argue instead that the regulative ideal of mutual understanding must be enlarged and recast so as to embrace both the concreteness of otherness and the indeterminacy of social identities and relations. For it is precisely the indeterminate nature of social relations that keeps ever before us the possibility of political transformation. Such transformations do not occur automatically, as implied in the mechanistic models of systemically guaranteed resistances and subversions, but rather through processes of mutual understanding and dialogue.

With the aim of opening up but also justifying Habermas's theory, I want to place Habermas in relation to Ernesto Laclau and Chantal Mouffe, two of his most trenchant critics. ${ }^{65}$ In Hegemony and Social Strategy: Towards a Radical Democratic Politics, Laclau and Mouffe aim to redress what they identify in classical Marxism as the reduction of the concrete to the abstract on the level of social as well as historical understanding. Classical Marxism reduces divergent subjectpositions to a single (class) position; likewise, any historical moment, including the present, is apprehended only as a point within a trajectory determined a priori. Reading from within the more openended and versatile concept of hegemony, Laclau and Mouffe describe the subject and the social through a concept of textual polysemy: "The category of the subject is penetrated by the same ambiguous, incomplete, and polysemical character which overdetermination as-

64. Dews, Logics of Disintegration 221.

65. In New Reflections on the Revolution of Our Time, Ernesto Laclau begins by defining his project in opposition to Habermas's, yet never really directly engages his theories. However, he does append to the volume an essay by Slavoj Zižek that casts the ideal speech situation as a fetish. See also Chantal Mouffe, "Radical Democracy" 31-32. 
signs to every discursive entity." ${ }^{\prime 66}$ We must recognize and trace overdeterminations rather than perceive subjects as unitary or fixed; this is the first step toward enabling "the possibility of the deepening of a pluralist and democratic conception." ${ }^{167}$

The problem Laclau and Mouffe set for themselves is to avoid an absolute dispersion or atomism while still assiduously renouncing any regressive appeal to a transcendental subject. Crucial to their reconception is the principle of "antagonism," a category of social interaction defined not positively but rather against a notion of "opposition" that regressively conceives identities that face off as a priori fixities. Antagonism-unstable, ever shifting-reflects the partial and precarious nature of all identification. Laclau and Mouffe bring before us the force of such precariousness precisely through the evocation of an encounter: "The presence of the 'Other' prevents me from being totally myself":

Insofar as there is an antagonism, I cannot be a full presence for myself. But nor is the force that antagonizes such a presence: its objective being is a symbol of my non-being, and, in this way, it is overflowed by a plurality of meanings which prevent its being fixed as full positivity. Real opposition is an objective relation-that is, determinable, definable-among things; contradiction is an equally definable relation among concepts; antagonism constitutes the limits of every objectivity, which is revealed as a partial and precarious objectification. ${ }^{68}$

For Laclau and Mouffe, antagonism is a function of the radical contingency of the social; but rather than serving to render politics impossible, it serves as the precondition for transformation, and precisely at the level of social alliances. The radical nonfixity of identity gives us the freedom collectively to construct new hegemonies that will emerge through mutually transforming encounters between variously constituted groups. Such social processes are vital to progressive social transformation: "For there to be a 'democratic equivalence' we need the construction of a new 'common sense' which changes the identity of the different groups in such a way that demands are articulated equivalentially with those of the oth-

66. Ernesto Laclau and Chantal Mouffe, Hegemony and Socialist Strategy 121.

67. Laclau and Mouffe, Hegemony and Socialist Strategy 166.

68. Laclau and Mouffe, Hegemony and Socialist Strategy 125. 
ers. ${ }^{\prime 69}$ In this conception no form of fixed identity can be said to constitute the groups whose identity is produced and transformed through their various encounters and struggles with one another: "Equivalence is always hegemonic insofar as it does not simply establish an 'alliance' between given interests, but modifies the identity of the forces engaging in that alliance. ${ }^{\prime 70}$

Laclau and Mouffe's "radical relationalism of social identities" derives from a poststructuralist linguistic model and hence might seem, in this respect, to elaborate the ambiguities and instabilities of identity from a systems perspective. Yet we must keep in mind the primacy of intersubjective "antagonism," which is not elaborated from such a perspective. Indeterminacy becomes simply the condition of our irreducibly social identities that enables us endlessly to renegotiate and recreate our relations to others, as both individuals and members of nonreified collectives. That is, indeterminacy serves as the precondition but not the guarantee of political transformation. Only in and through the relations between subjects and groups are identities constituted and transformed; so in an important sense, and quite self-consciously, Laclau and Mouffe avoid the objectivism that inhabits poststructuralist systems theory while still forwarding a general theoretical account of the social.

An important question remains, however: does the concept of antagonism as constitutive of the social entirely foreclose or undermine any conception of communicative reason? In their more recent work, these thinkers have stressed the importance of the situated social agent through a reconstructed conception of Gadamer's phronesis (detached from its traditionalist resonances and reconceived more along the lines of the Wittgensteinian language game). ${ }^{71} \mathrm{Al}-$ though Laclau and Mouffe themselves see Habermas as engaged in the deluded project of attempting to guarantee the political efficacy of Enlightenment ideals, I suggest that there are tacit similarities between Habermas's conception of communicative action as the site of emancipatory potential and Laclau's developing account of hegemonic struggle. In an article that extends many of the claims in Hegemony and Socialist Strategy, Laclau elaborates in further detail how antifoundationalism can serve as the ground for a profound political optimism. He does so precisely by specifying a communi-

69. Laclau and Mouffe, Hegemony and Socialist Strategy 183.

70. Laclau and Mouffe, Hegemony and Socialist Strategy 183-84.

71. See Mouffe, "Radical Democracy"; Laclau, "Politics and the Limits of Modernity" 63-82. 
cative model of social praxis, arguing that society should be "understood as a vast argumentative texture through which people construct their own reality." He further claims that "inasmuch as argument and discourse constitute the social, their open-ended character becomes the source of a greater activism and a more radical libertarianism. ${ }^{\prime 72}$

But if Laclau is to justify a transformative praxis through a conception of society as fundamentally discursive, he must presuppose communicative norms, even in the face of the radical disruptions of antagonism. In order to appropriate the radically open and transformable character of social identities for a new hegemony-in order to articulate a common sense-we must presuppose some form of communicative understanding, unless we are to imagine that such articulations take place behind the backs of social subjects. It seems to me that the turn to phronesis is itself an attempt to render more explicit those communicative and reconstructive processes involved in mutually transforming intersubjective alliances. Yet it also seems that an unacknowledged intersubjective ideal underlies the whole concept of a new common sense. We may acknowledge that power is constitutive of all interactions, and that identity is indeterminate, and still aim to foster regulative ideals of equality and reciprocal respect. Otherwise, what meaning does "democracy" or "the left" have? In other words, if the Habermasian account must be revised to give prominence to social indeterminacy and concrete social positions, then the ideas of "equivalences" and "common sense" must be deepened through an acknowledgment of the intersubjective ideals that underlie them. Insofar as it serves merely as the foundation of a procedural model, communicative reason does not need to be yoked to essentializing conceptions of identity, whether individual or social. A regulative ideal of mutual understanding does not render identity determinate, it merely renders politics possible.

Laclau and Mouffe generate an entirely promising vision of communicative politics in their thoroughgoing reconceptualization of rights. According to them, a radical democratic politics would be based on a demand to rights constituted through variable contexts and not determined a priori:

The idea of 'natural' rights prior to society-and indeed, the whole of the false dichotomy individual/society—should be abandoned,

72. Laclau, "Politics and the Limits of Modernity" 79. 
and replaced by another manner of posing the problem of rights. It is never possible for individual rights to be defined in isolation, but only in the context of social relations which define determinate subject positions. As a consequence, it will always be a question of rights which involve other subjects who participate in the same social relation. ${ }^{73}$

Given the multiplicity of subject-positions, as well as the fundamental unevenness of the social, any demand for rights must thus take into account the rights claims of other groups: a reconstructed principle of equality must thus be balanced by a reconstructed principle of liberty, which recognizes differences and hence leads to the notion of plurality. Similarly, Benhabib wishes to balance the category of the general other (which would correspond to the struggle for equality) with the category of the concrete other (which enables and ensures a plural democracy). More important to the argument I have been making in this Afterword, Laclau and Mouffe's different manner of posing the problem of rights, their emphasis on social contexts and indeterminacy, still relies, if only implicitly, on a fundamental appeal to the forms of mutual recognition on which rights rest. Hence I find peculiar their refusal to recognize the importance of the theory of communicative action.

There is a discernible similarity between the impasses of the Victorian rhetoric of fallenness and the impasses of those poststructuralisms that allow a systems perspective to dominate their account of the social world. This book has argued that mutually transforming reciprocal recognition, a condition of any democratic and emancipatory practice, is an experience fundamentally foreclosed in conventional representations of Victorian fallenness as well as in those poststructuralisms that allow a systems perspective to dominate their account of the social world. Such contemporary recapitulations fail to express the fundamentally intersubjective, participatory, and open-ended nature of the social world. In this Afterword, I have tried to elaborate those theoretical positions that might help us to further such an understanding of the social world, just as my readings of Victorian texts stressed critical or revisionist moments. We might in fact contemplate those challenges anew in light of the

73. Laclau and Mouffe, Hegemony and Socialist Strategy 184. 
discussion I have offered here, to see to what extent they manifest the kind of acknowledgment of intersubjective practices that I have argued is vital to democratic possibilities. Gaskell's vision at the end of North and South comes closest to the Habermasian communicative ideal, and her works generally do not separate sympathy or feeling from the ideal of mutual understanding. D. G. Rossetti's "Jenny," insofar as it critiques the objectifying stance of the speaker, indirectly suggests positive aspects of intersubjective indeterminacy; and Barrett Browning does so more explicitly through her insistence on a productive interplay between aesthetic and intersubjective experience. While I would not want to reduce these historical texts to their usefulness for contemporary social theory, I do believe that their challenges to the Victorian rhetoric of fallenness have resonances for contemporary theory.

But this Afterword has been most concerned to demonstrate that the systems-dominated poststructuralist paradigms do not adequately theorize their normative commitments. The project of communicative ethics, as I have tried to show, allows us to do more than describe and reinscribe the impasses of constructionism. In place of reductive or distorting social and linguistic determinisms, it offers a more coherent and comprehensive theory of the mutually constitutive agencies and antagonisms that make up our intersubjective practices. 
